\title{
Analysis of Some Trace Metals in Fish Species after Preconcentration with Congo Red on Amberlite XAD-7 Resin by Flame Atomic Absorption Spectrometry
}

\author{
Güzin Alpdoğan, Nevim San, and Şule Dinç Zor \\ Department of Chemistry, Faculty of Science and Arts, Yildiz Technical University, Davutpasa, 34220 Istanbul, Turkey \\ Correspondence should be addressed to Güzin Alpdoğan; galpdogan@yahoo.com
}

Received 24 August 2016; Revised 26 October 2016; Accepted 30 October 2016

Academic Editor: Daryoush Afzali

Copyright (C) 2016 Güzin Alpdoğan et al. This is an open access article distributed under the Creative Commons Attribution License, which permits unrestricted use, distribution, and reproduction in any medium, provided the original work is properly cited.

\begin{abstract}
A new procedure for separation and preconcentration of trace amounts of $\mathrm{Cu}(\mathrm{II}), \mathrm{Ni}(\mathrm{II}), \mathrm{Fe}(\mathrm{III}), \mathrm{Zn}(\mathrm{II}), \mathrm{Cr}(\mathrm{III}), \mathrm{Cd}(\mathrm{II}), \mathrm{and} \mathrm{Pb}$ (II) in fish samples was proposed. The procedure is based on the adsorption of these metal ions on the column of Amberlite XAD-7 as congo red complexes prior to their determination by flame atomic absorption spectrometry (FAAS). Several factors that can affect the sorption and elution efficiency of the metal ions were investigated and optimized. The sorption was quantitative in the $\mathrm{pH}$ range of 6.0-9.0 for $\mathrm{Cu}(\mathrm{II})$ and $\mathrm{Ni}(\mathrm{II}), 5.5-8.0$ for $\mathrm{Fe}(\mathrm{III}), 6.0-8.5$ for $\mathrm{Zn}$ (II) and $\mathrm{Cd}(\mathrm{II})$, and 7.0-8.5 for $\mathrm{Cr}$ (III) and $\mathrm{Pb}$ (II). The optimum $\mathrm{pH}$ for simultaneous retention was 7.5. The sorption capacity of the resin was found to be $0.89,0.72,0.82,0.61,0.53,0.84$, and $0.78 \mathrm{mg} / \mathrm{g}$ for $\mathrm{Cu}(\mathrm{II}), \mathrm{Ni}(\mathrm{II}), \mathrm{Fe}(\mathrm{III}), \mathrm{Zn}(\mathrm{II}), \mathrm{Cr}(\mathrm{III}), \mathrm{Cd}(\mathrm{II})$, and $\mathrm{Pb}(\mathrm{II})$, respectively. The precision of the method was evaluated as the relative standard deviation obtained by analyzing a series of six replicates and below $6 \%$ for all seven elements. The validation of the method was performed by the analysis of certified reference materials. The proposed method was successfully applied to separation/ preconcentration and determination of these metals in fish samples.
\end{abstract}

\section{Introduction}

Due to human activities including agriculture, industrial production, mining, and transportation, metal ions have released into surface and ground waters, soil, and atmosphere. In particular, waters and soils contaminated with toxic metals may lead to accumulation of them in foodstuff. Ultimately, the uptake of metal ions associated with the consumption of these foods by human beings can cause a possible risk to public health. Therefore, World Health Organization (WHO) and European Community recommend controlling toxic metal ions in food sources in order to guarantee food safety [1-5]. Since the health and ecological problems in connection with environmental contamination increase, the quantification of heavy metal ions at trace level in various samples has become an important issue in the analytical laboratories [6]. Flame atomic absorption spectrometry (FAAS) is widely used and preferred for determination of toxic elements, but appropriate separation and preconcentration steps before analysis by
FAAS are usually required because of the complex matrixes and the low concentrations of the metal ions in the real samples [7]. Hence, various separation and preconcentration procedures, including solvent extraction, cloud point extraction (CPE), solid phase extraction (SPE), and coprecipitation, have been reported for trace metal ion analysis in different matrices [8-14]. Among these preconcentration techniques, SPE has been utilized in many studies due to its advantages such as simplicity, rapidity, easy applicability to the preconcentration methods which increase sensitivity, and good separation capacity for target analytes. SPE has a relatively high preconcentration factor and also is able to apply to large volume samples without contamination $[15,16]$. Although many SPE studies have been published employing adsorbents including activated carbon, chelating resins, ion exchange resins, and others, some SPE procedures do not have practicability due to long preconcentration time [17, 18]. Therefore, it can be said that a well-chosen adsorbent determines the efficiency of the SPE technique. Amberlite 
$\mathrm{XAD}^{\circledR}$ resins which are able to adsorb metal complexes have received a great deal of attention because of versatile usage with or without derivatization [19-22]. In particular, Amberlite XAD-7 resin possessing an intermediate polarity and hydrophilic surface as a highly crosslinked macroreticular acrylic resin (polyacrylic acid ester polymer) has been performed in SPE studies [23-25]. Moreover, the surface area and sorption capacity of Amberlite XAD-7 resin which has a surface area of $450 \mathrm{~m}^{2} / \mathrm{g}$ are higher than Amberlite XAD-2 whose surface area is $330 \mathrm{~m}^{2} / \mathrm{g}$ [26].

A member of anionic azo dyes, congo red (CR), and (disodium 4-amino-[4-[4-(1-amino-4-sulfonato-naphthalen2-yl) diazenylphenyl] phenyl]diazenyl-naphthalene-1sulfonate) has displayed excellent complexing ability for some metal ions and analytical application of this ligand in the potentiometric and electrical conductivity studies was well established $[27,28]$. CR derivatized microspheres were used for the removal of heavy metal ions and metal chelate affinity of albumin [29-31]. A SPE procedure for the separation and preconcentration of trace amounts of Fe(III), $\mathrm{Mn}(\mathrm{II}), \mathrm{Ni}(\mathrm{II})$, and $\mathrm{Zn}(\mathrm{II})$ as their complexes in water and food samples on a multiwalled carbon nanotube (MWCNT) disk was published in literature [32]. But the combination of Amberlite XAD-7/CR has not yet been used for the separation/preconcentration of any metal ions.

In the presented study, a novel analytical method including the combination of SPE and FAAS for the preconcentration and separation of $\mathrm{Cu}(\mathrm{II}), \mathrm{Ni}(\mathrm{II}), \mathrm{Fe}(\mathrm{III}), \mathrm{Zn}$ (II), $\mathrm{Cr}$ (III), $\mathrm{Cd}(\mathrm{II})$, and $\mathrm{Pb}$ (II) ions on Amberlite XAD-7 as their congo red complexes was developed. After determining optimal experimental conditions, the proposed method was validated by analyzing the certified reference material. The metal ion contents of the fish species were eventually determined by using FAAS and the level of toxicity in fish samples was evaluated.

\section{Experimental}

2.1. Apparatus. The concentrations of metal ions were determined by FAAS technique according to the standard guideline of the manufacturer (Perkin-Elmer AAnalyst 700, Norwalk, USA). A Sartorius PP-15 model pH meter, with a glasselectrode employed was used for measuring $\mathrm{pH}$ values in the aqueous phase. For the sample digestion, Milestone Ethos D microwave system (Sorisole-Bg, Italy) was also used in the experiments.

2.2. Chemicals and Standard Solutions. Analytical reagentgrade chemicals were employed for the preparation of all solutions. Milli-Q water was used to prepare aqueous solutions (Millipore, Milford, MA, USA). Stock metal solutions, 1000 mg/L (Sigma Chemical Co., St. Louis, MO), were used for the preparation of standard and working solutions. Congo red (CR) solutions $(1.0 \mathrm{mmol} / \mathrm{L})$ were daily prepared by dissolving the required amounts of CR (Merck, Germany) in water. The $\mathrm{pH}$ of the model solution was adjusted to pH 2-3 with hydrochloric acid-potassium chloride, $\mathrm{pH}$ 4-6 with sodium acetate-acetic acid, and $\mathrm{pH}$ 7-10 with ammoniaammonium chloride buffer solutions.
Amberlite XAD-7 with surface area and bead size are $450 \mathrm{~m}^{2} / \mathrm{g}$ and $20-40$ mesh was purchased from Aldrich (Milwaukee, USA) and firstly allowed to stand in $1.0 \mathrm{~mol} / \mathrm{L}$ sodium hydroxide for $1 \mathrm{~h}$ and $4.0 \mathrm{~mol} / \mathrm{L}$ hydrochloride acid for $1 \mathrm{~h}$ before use. After separation by filtration, it was rinsed by distilled water and methanol. Finally, the dried XAD-7 resin was ground by means of agate mortar and kept in a desiccator.

2.3. Experimental Procedure. The proposed method was tested with model solutions containing metal ions $(30 \mu \mathrm{g}$ of $\mathrm{Pb}$ (II), $30 \mu \mathrm{g}$ of $\mathrm{Cr}$ (III), $20 \mu \mathrm{g}$ of $\mathrm{Fe}(\mathrm{III}), 15 \mu \mathrm{g}$ of $\mathrm{Cu}(\mathrm{II}), 15 \mu \mathrm{g}$ of $\mathrm{Ni}(\mathrm{II}), 10 \mu \mathrm{g}$ of $\mathrm{Cd}(\mathrm{II})$, and $10 \mu \mathrm{g}$ of $\mathrm{Zn}(\mathrm{II}))$ prior to its applications. $10 \mathrm{~mL}$ of appropriate buffer solution (in order to adjust the $\mathrm{pH}$ between 2 and 10, as given above) and $4.0 \mathrm{~mL} 1.0 \mathrm{mmol} / \mathrm{L} \mathrm{CR}$ solution were added to $50-60 \mathrm{~mL}$ of model solution. $0.5 \mathrm{~g}$ of XAD-7 filled column was pretreated with the relevant buffer solution. Metal-CR complexes were passed through the XAD-7 column at a flow rate of 5$10 \mathrm{~mL} / \mathrm{min}$. The adsorbed metal ions on the resin were then eluted with $5 \mathrm{~mL}$ of $3.0 \mathrm{~mol} / \mathrm{L} \mathrm{HNO}_{3}$ in acetone. The solution was evaporated almost to dryness and diluted to $5 \mathrm{~mL}$ with $0.1 \mathrm{~mol} / \mathrm{L} \mathrm{HNO}_{3}$. The eluent was analyzed by FAAS for the determination of metal concentrations.

2.4. Sample Collection and Preparation. Fish samples of Dicentrarchus labrax, Sparus aurata, Mullus barbatus, and Merlangius merlangus euxinus species were purchased from the fish market in Istanbul, Turkey. Fishes were dissected to separate organs (scale, skin, muscle, gill, and liver) according to FAO methods [33]. The collected samples were packed on ice for transport to the laboratory and stored at $-4^{\circ} \mathrm{C}$ until analyzed.

For the fish analysis, about 1 gram of sample (scale, skin, muscle, gill, or liver) was digested with $6 \mathrm{~mL}$ of $65 \%$ nitric acid and $2 \mathrm{~mL}$ of $30 \%$ hydrogen peroxide in microwave digestion system and diluted to $10 \mathrm{~mL}$ with Milli-Q water. A blank digest was performed in a similar manner (digestion conditions for microwave system; $2 \mathrm{~min}$ for $250 \mathrm{~W}, 2 \mathrm{~min}$ for $0 \mathrm{~W}, 6 \mathrm{~min}$ for $250 \mathrm{~W}, 6 \mathrm{~min}$ for $400 \mathrm{~W}$, and $10 \mathrm{~min}$ for $500 \mathrm{~W}$, vent: $8 \mathrm{~min}$, resp.). The preconcentration procedure given above was also applied to the real samples. The final volume was $5 \mathrm{~mL}$. In order to assess the accuracy of the developed method, the certified reference material NRCC-DORM-2Dogfish muscle which was obtained from National Research Council, Canada, was used and digested in accordance with the digestion method described above.

\section{Results and Discussion}

3.1. pH Effect. Target analytes were separated and preconcentrated on Amberlite XAD-7 in the $\mathrm{pH}$ range of 2-10, while keeping all other parameters constant for the model solutions. Blank studies containing no analyte were also performed by the same preconcentration procedure mentioned above. The results showed that the sorption was quantitative for $\mathrm{Cu}(\mathrm{II})$ and $\mathrm{Ni}(\mathrm{II})$ in the $\mathrm{pH}$ range of 6.0-9.0; $\mathrm{Fe}(\mathrm{III}), 5.5-8.0 ; \mathrm{Zn}$ (II) and $\mathrm{Cd}(\mathrm{II}), 6.0-8.5$; and $\mathrm{Cr}(\mathrm{III})$ and $\mathrm{Pb}(\mathrm{II}), 7.0-8.5$. As can be inferred from the results, the quantitative recovery values for 
TABLE 1: Effect of type and concentration of eluting agent on the recovery of analytes $(N=4)$.

\begin{tabular}{|c|c|c|c|c|c|c|c|}
\hline \multirow{2}{*}{ Eluent conditions ${ }^{\mathrm{a}}$} & \multicolumn{7}{|c|}{ Recovery (\%) } \\
\hline & $\mathrm{Cu}(\mathrm{II})$ & $\mathrm{Ni}(\mathrm{II})$ & $\mathrm{Fe}(\mathrm{III})$ & $\mathrm{Zn}(\mathrm{II})$ & $\mathrm{Cr}(\mathrm{III})$ & $\mathrm{Cd}(\mathrm{II})$ & $\mathrm{Pb}(\mathrm{II})$ \\
\hline $\mathrm{HCl}\left(2.0 \mathrm{~mol} \mathrm{~L}^{-1}\right)$ & 75.4 & 69.4 & 88.0 & 48.6 & 94.2 & 35.2 & 29.5 \\
\hline $\mathrm{HClO}_{4}\left(2.0 \mathrm{~mol} \mathrm{~L}^{-1}\right)$ & 24.6 & 57.8 & 61.2 & 55.0 & 46.7 & 33.3 & 29.5 \\
\hline $\mathrm{H}_{2} \mathrm{SO}_{4}\left(2.0 \mathrm{~mol} \mathrm{~L}^{-1}\right)$ & 68.7 & 99.5 & 28.5 & 64.2 & 37.8 & 39.8 & 62.5 \\
\hline $\mathrm{HNO}_{3}\left(1.0 \mathrm{~mol} \mathrm{~L}^{-1}\right)$ & 93.4 & 90.1 & 89.6 & 88.7 & 86.9 & 87.5 & 85.8 \\
\hline $\mathrm{HNO}_{3}\left(2.0 \mathrm{~mol} \mathrm{~L}^{-1}\right)$ & 97.5 & 94.3 & 93.2 & 94.6 & 91.5 & 92.8 & 91.7 \\
\hline $\mathrm{HNO}_{3}\left(3.0 \mathrm{~mol} \mathrm{~L}^{-1}\right)$ & 100.2 & 100.4 & 99.5 & 99.2 & 95.8 & 99.6 & 98.9 \\
\hline
\end{tabular}

${ }^{\mathrm{a}}$ Volume of eluent was $5 \mathrm{~mL}$; all solutions were in acetone.

all studied metal ions were obtained in the range of $\mathrm{pH} 7.0-$ 8.0. Therefore, $\mathrm{pH} 7.5$ was chosen as the optimum $\mathrm{pH}$ value in further experiments. In order to adjust this $\mathrm{pH}$, ammoniaammonium chloride buffer solution was used.

3.2. Effect of the Type, Concentration, and Volume of the Eluent. A proper eluent is required for the quantitative recovery of the retained analytes on the adsorbent. Various acids with different concentrations were examined to determine the appropriate eluent for extraction procedure (Table 1). According to Table $1,3.0 \mathrm{~mol} \mathrm{~L}-1 \mathrm{HNO}_{3}$ in acetone is the best eluent for the quantitative elution of metal ions studied. In order to achieve high enrichment factors, the volume of eluent was investigated in the range of $2-6 \mathrm{~mL}$ of $\mathrm{HNO}_{3}$ in acetone. When using $5 \mathrm{~mL}$ of $3.0 \mathrm{~mol} / \mathrm{L} \mathrm{HNO}_{3}$ in acetone the recoveries were quantitative in the proposed method. Hence $5.0 \mathrm{~mL}$ was chosen as the eluent volume.

3.3. Effect of Sample Volume. The maximum applicable sample volume must be established in order to analyze real samples. The effect of sample volume on the sorption of metal ions was studied by passing $250-2000 \mathrm{~mL}$ volumes through the adsorbent filled column and was shown in Figure 1. According to these results, it was revealed that the adsorption of metal ions with $0.5 \mathrm{~g}$ resin was not affected by sample volume even at $1500 \mathrm{~mL}$. So, the preconcentration factor was found to be 300 for the studied metal ions in the event $5 \mathrm{~mL}$ of the final solution after the developed SPE procedure.

3.4. Effect of Flow Rate. The flow rates for sample solution and eluent are crucial factors to achieve quantitative retention and elution, respectively. Therefore, the effects of the sample and eluent flow rates on the retentions and recoveries of metal ions were also investigated in the flow rate range of 1-9 $\mathrm{mL} / \mathrm{min}$. Figures 2 and 3 depict the results obtained for sample and eluent flow rates, respectively. According to these results, all analytes were quantitatively sorbed and recovered on the Amberlite XAD-7 adsorbent in the sample and eluent flow range of $1-7 \mathrm{~mL} / \mathrm{min}$. So, $5 \mathrm{~mL} / \mathrm{min}$ was chosen as sample and eluent flow rate for further experiments.

3.5. Effect of Complexing Reagent Concentration. For the purpose of determining the concentration of $\mathrm{CR}$ required for quantitative recoveries, the developed preconcentration method was applied. Firstly, the same procedure was studied at $\mathrm{pH} 7.5$ without reagent. It appears that the investigated

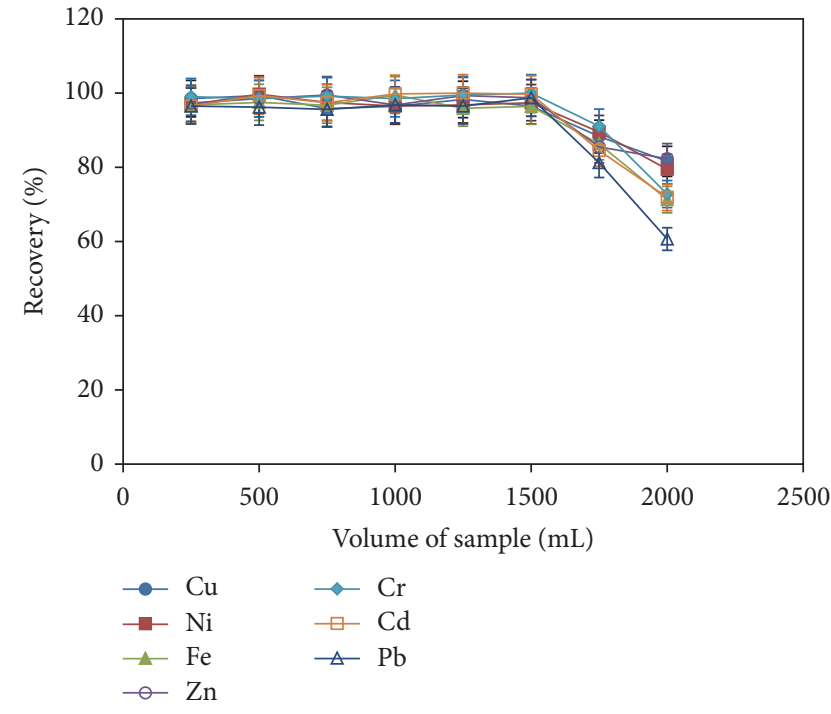

FIgURE 1: Effect of sample volume $(\mathrm{pH}=7.5$; amount of metal ions: $30 \mu \mathrm{g} \mathrm{Pb}(\mathrm{II})$ and $\mathrm{Cr}(\mathrm{III}), 20 \mu \mathrm{g} \mathrm{Fe}(\mathrm{III}), 15 \mu \mathrm{g} \mathrm{Cu}(\mathrm{II})$ and $\mathrm{Ni}(\mathrm{II})$, and $10 \mu \mathrm{g} \mathrm{Cd}(\mathrm{II})$ and $\mathrm{Zn}(\mathrm{II})$; CR amount: $1.0 \mathrm{mmol} / \mathrm{L}$; amount of resin: $0.5 \mathrm{~g}$; flow rate: $5.0 \mathrm{~mL} / \mathrm{min}$; final volume: $5 \mathrm{~mL}$ and $N=3$ ).

metal ions are not quantitatively recovered without CR. Hence, the experiments were carried out with the various volumes of $1.0 \mathrm{mmol} / \mathrm{L} \mathrm{CR}$ at $\mathrm{pH} 7.5$. The obtained results showed that there is a positive correlation between recovery of the metal ions and concentration of CR. The recovery values achieved a constant value (95\%) when $4.0 \mathrm{~mL}$ of $1.0 \mathrm{mmol} / \mathrm{L} \mathrm{CR}$ was used. Due to low level of the studied metal ion amounts in real samples, further studies were performed at a CR concentration of $4.0 \mathrm{~mL}$ of $1.0 \mathrm{mmol} / \mathrm{L}$.

3.6. Total Sorption Capacity. The total sorption capacity of the metal ions was determined by saturating $0.5 \mathrm{~g}$ of Amberlite XAD-7 and a suitable aliquot of metal ion complexes. The sorption capacity for each analyte ion on the adsorbent was calculated from the difference between the metal ion concentration before and after desorption. The obtained results are given in Table 2.

3.7. Reusability of the Resin. In order to test the resin reusability, the metal complexes were sorbed and desorbed on $0.5 \mathrm{~g}$ of Amberlite XAD-7 several times using a solution $(50 \mathrm{~mL})$ with 


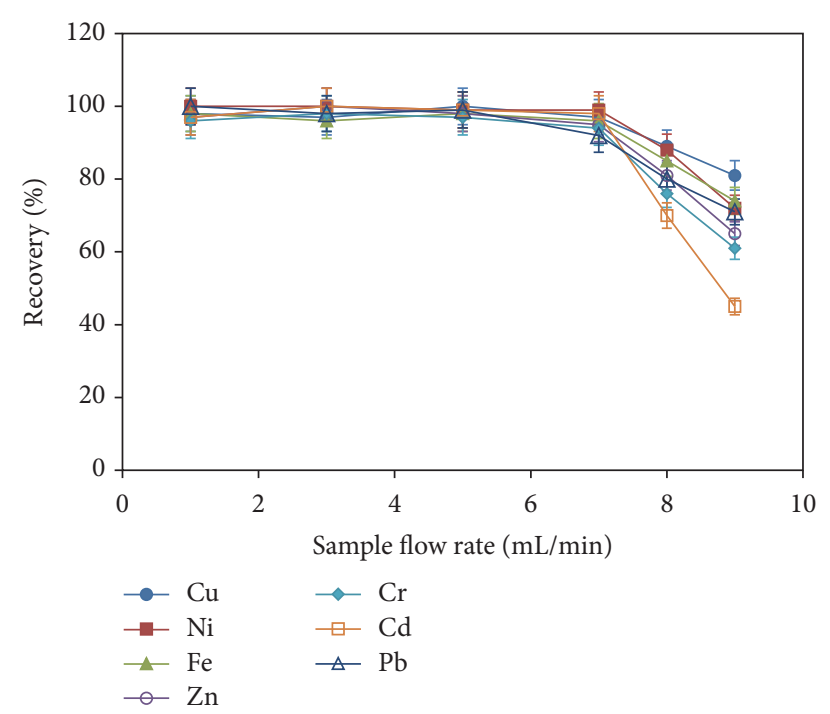

FIGURE 2: Effect of flow rates of sample solution on the retentions of analytes ( $\mathrm{pH}=7.5$; amount of metal ions: $30 \mu \mathrm{g} \mathrm{Pb}$ (II) and $\mathrm{Cr}(\mathrm{III})$, $20 \mu \mathrm{g} \mathrm{Fe}(\mathrm{III}), 15 \mu \mathrm{g} \mathrm{Cu}(\mathrm{II})$ and $\mathrm{Ni}(\mathrm{II})$, and $10 \mu \mathrm{g} \mathrm{Cd}(\mathrm{II})$ and $\mathrm{Zn}(\mathrm{II})$; CR amount: $1.0 \mathrm{mmol} / \mathrm{L}$; amount of resin: $0.5 \mathrm{~g}$; final volume: $5 \mathrm{~mL}$ and $N=3$ ).

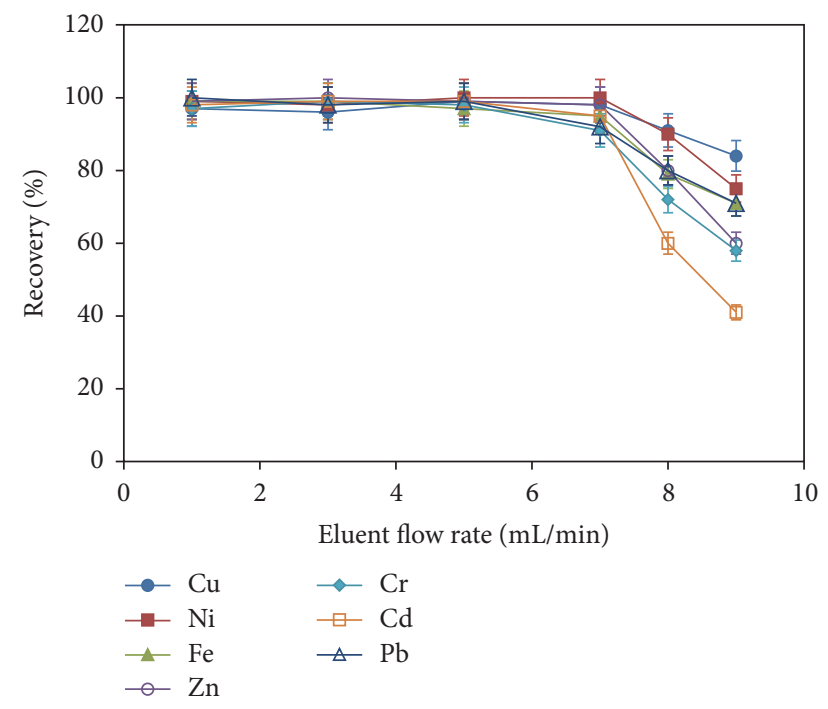

FIgURE 3: The influence of flow rates of eluent solution on the recoveries of the analyte ions with CR on Amberlite XAD-7 ( $\mathrm{pH}=$ 7.5; amount of metal ions: $30 \mu \mathrm{g} \mathrm{Pb}(\mathrm{II})$ and $\mathrm{Cr}(\mathrm{III}), 20 \mu \mathrm{g} \mathrm{Fe}(\mathrm{III})$, $15 \mu \mathrm{g} \mathrm{Cu}(\mathrm{II})$ and $\mathrm{Ni}(\mathrm{II})$, and $10 \mu \mathrm{g} \mathrm{Cd}(\mathrm{II})$ and $\mathrm{Zn}(\mathrm{II})$; CR amount: $1.0 \mathrm{mmol} / \mathrm{L}$; amount of resin: $0.5 \mathrm{~g}$; final volume: $5 \mathrm{~mL}$ and $N=3$ ).

a concentration of $5-50 \mu \mathrm{g} / \mathrm{mL}$ under the optimised experimental conditions. As can be seen in Figure 4, it appears that the sorption capacity after 60 cycles of sorption and desorption does not vary more than $2.5 \%$. As a consequence, it is possible to reuse the resin without any change in its sorption behavior up to 60 cycles.

3.8. Effect of Foreign Ions on Recovery. In order to evaluate the analytical applicability of the developed method, the effect
TABLE 2: Total sorption capacity of the metal ions on the Amberlite XAD-7 (amount of resin: 0.5 g, metal ions: $50-800 \mu \mathrm{g}$, and $\mathrm{pH}: 7.5$ ).

\begin{tabular}{lc}
\hline Metal & Capacity $(\mu \mathrm{g} / \mathrm{g})$ resin \\
\hline $\mathrm{Cu}(\mathrm{II})$ & 890 \\
$\mathrm{Ni}(\mathrm{II})$ & 720 \\
$\mathrm{Fe}(\mathrm{III})$ & 820 \\
$\mathrm{Zn}(\mathrm{II})$ & 610 \\
$\mathrm{Cr}(\mathrm{III})$ & 530 \\
$\mathrm{Cd}(\mathrm{II})$ & 840 \\
$\mathrm{~Pb}(\mathrm{II})$ & 780 \\
\hline
\end{tabular}

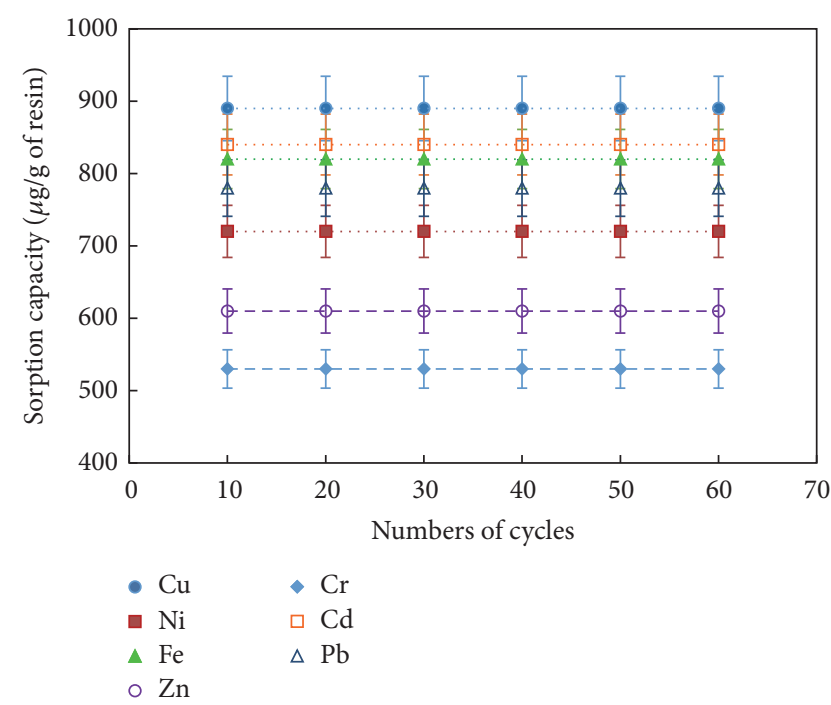

FIgURE 4: The effect of column reuse on recovery of metal ions by Amberlite XAD-7 resin at optimum conditions.

of some foreign ions was investigated. As is also understood from the literature, the effect of humic substances was less studied in the reported procedures [34, 35]. Different anions and cations which are concomitant with the metal ions present at the trace level in several samples and humic substances had no interference in the sorption of these metal ions up to considerable concentrations (Table 3). The tolerance limit is defined as the ion concentration causing a relative error smaller than $\pm 4 \%$ related to the preconcentration and determination of the analyte ions.

3.9. Accuracy of the Method. The accuracy of the proposed method was controlled by the analysis of certified reference material (NRCC-DORM-2-Dogfish muscle). As can be seen in Table 4, the results obtained showed good agreement with the certified value. Also, it can be said that the developed SPE method is free from matrix effects.

The relative standard deviations (RSD, $N=6$ ) with regard to the determinations in fish samples were found to be lower than $6 \%$. The detection limits (LOD, $N=6$ ) based on the $3 \mathrm{Sb}$ criterion for $\mathrm{Cu}(\mathrm{II}), \mathrm{Ni}(\mathrm{II}), \mathrm{Fe}(\mathrm{III}), \mathrm{Zn}(\mathrm{II}), \mathrm{Cr}(\mathrm{III}), \mathrm{Cd}(\mathrm{II})$, 
TABLE 3: Tolerance limit of foreign species (in binary mixtures) on sorption of metal ions (column parameter: $100 \mathrm{~mL}$ of solution; $10 \mu \mathrm{g} / \mathrm{L}$ metal ions; $0.5 \mathrm{~g}$ resin).

\begin{tabular}{|c|c|c|c|c|c|c|c|}
\hline \multirow{2}{*}{ Foreign species } & \multicolumn{7}{|c|}{ Tolerance ratio [foreign species $(\mu \mathrm{g} / \mathrm{L}) /$ metal ion $(\mu \mathrm{g} / \mathrm{L})]$} \\
\hline & $\mathrm{Cu}(\mathrm{II})$ & $\mathrm{Ni}(\mathrm{II})$ & $\mathrm{Fe}(\mathrm{III})$ & $\mathrm{Zn}(\mathrm{II})$ & $\mathrm{Cr}(\mathrm{III})$ & $\mathrm{Cd}(\mathrm{II})$ & $\mathrm{Pb}(\mathrm{II})$ \\
\hline $\mathrm{Na}^{+}(\mathrm{NaCl})$ & $2.46 \times 10^{6}$ & $3.51 \times 10^{6}$ & $1.84 \times 10^{6}$ & $1.99 \times 10^{6}$ & $1.67 \times 10^{6}$ & $1.77 \times 10^{6}$ & $1.68 \times 10^{6}$ \\
\hline $\mathrm{K}^{+}(\mathrm{KCl})$ & $1.98 \times 10^{6}$ & $3.12 \times 10^{6}$ & $4.02 \times 10^{6}$ & $1.55 \times 10^{6}$ & $1.98 \times 10^{6}$ & $1.82 \times 10^{6}$ & $0.97 \times 10^{6}$ \\
\hline $\mathrm{NH}_{4}^{+}\left(\mathrm{NH}_{4} \mathrm{Cl}\right)$ & $1.09 \times 10^{6}$ & $2.31 \times 10^{6}$ & $3.68 \times 10^{6}$ & $1.38 \times 10^{6}$ & $1.66 \times 10^{6}$ & $1.65 \times 10^{6}$ & $1.02 \times 10^{6}$ \\
\hline $\mathrm{Cl}^{-}(\mathrm{NaCl})$ & $2.98 \times 10^{6}$ & $3.98 \times 10^{6}$ & $4.77 \times 10^{6}$ & $1.79 \times 10^{6}$ & $1.51 \times 10^{6}$ & $7.19 \times 10^{6}$ & $1.75 \times 10^{6}$ \\
\hline $\mathrm{SO}_{4}{ }^{2-}\left(\mathrm{Na}_{2} \mathrm{SO}_{4}\right)$ & $3.78 \times 10^{6}$ & $3.94 \times 10^{6}$ & $4.02 \times 10^{6}$ & $4.12 \times 10^{6}$ & $7.89 \times 10^{6}$ & $8.14 \times 10^{6}$ & $3.75 \times 10^{6}$ \\
\hline $\mathrm{NO}_{3}^{-}\left(\mathrm{NaNO}_{3}\right)$ & $3.9 \times 10^{6}$ & $3.47 \times 10^{6}$ & $3.88 \times 10^{6}$ & $4.17 \times 10^{6}$ & $8.13 \times 10^{6}$ & $1.5 \times 10^{6}$ & $4.12 \times 10^{6}$ \\
\hline $\mathrm{PO}_{4}{ }^{3-}\left(\mathrm{Na}_{3} \mathrm{PO}_{4}\right)$ & $6.8 \times 10^{5}$ & $6.72 \times 10^{5}$ & $7.75 \times 10^{5}$ & $4.43 \times 10^{5}$ & $6.76 \times 10^{5}$ & $2.62 \times 10^{5}$ & $4.68 \times 10^{5}$ \\
\hline $\mathrm{CO}_{3}^{2-}\left(\mathrm{Na}_{2} \mathrm{CO}_{3}\right)$ & $2.47 \times 10^{6}$ & $2.43 \times 10^{6}$ & $2.83 \times 10^{6}$ & $1.39 \times 10^{6}$ & $7.41 \times 10^{6}$ & $1.35 \times 10^{6}$ & $2.12 \times 10^{6}$ \\
\hline Citrate (sodium citrate) & $1.34 \times 10^{4}$ & $2.49 \times 10^{4}$ & $3.53 \times 10^{4}$ & $2.12 \times 10^{4}$ & $9.52 \times 10^{4}$ & $2.17 \times 10^{4}$ & $2.71 \times 10^{4}$ \\
\hline Tartrate (NaKtartrate) & $1.98 \times 10^{3}$ & $6.99 \times 10^{3}$ & $8.81 \times 10^{3}$ & $3.17 \times 10^{3}$ & $6.41 \times 10^{3}$ & $3.65 \times 10^{3}$ & $6.23 \times 10^{3}$ \\
\hline Oxalate $\left(\mathrm{Na}_{2} \mathrm{C}_{2} \mathrm{O}_{4}\right)$ & $1.51 \times 10^{3}$ & $7.14 \times 10^{3}$ & $8.62 \times 10^{3}$ & $1.85 \times 10^{3}$ & $4.12 \times 10^{3}$ & $6.17 \times 10^{3}$ & $1.98 \times 10^{3}$ \\
\hline Fulvic acid & 18 & 77 & 35 & 31 & 52 & 29 & 30 \\
\hline Humic acid & 33 & 134 & 74 & 87 & 83 & 45 & 68 \\
\hline $\mathrm{CH}_{3} \mathrm{COO}^{-}\left(\mathrm{CH}_{3} \mathrm{COONa}\right)$ & $2.17 \times 10^{5}$ & $7.23 \times 10^{5}$ & $8.12 \times 10^{5}$ & $3.43 \times 10^{5}$ & $2.78 \times 10^{5}$ & $1.47 \times 10^{5}$ & $3.12 \times 10^{5}$ \\
\hline $\mathrm{Ca}^{2+}\left(\mathrm{CaCl}_{2}\right)$ & $4.53 \times 10^{5}$ & $6.98 \times 10^{5}$ & $4.22 \times 10^{5}$ & $4.52 \times 10^{5}$ & $6.23 \times 10^{5}$ & $2.13 \times 10^{5}$ & $3.98 \times 10^{5}$ \\
\hline $\mathrm{Mg}^{2+}\left(\mathrm{MgCl}_{2}\right)$ & $4.02 \times 10^{5}$ & $7.75 \times 10^{5}$ & $6.23 \times 10^{5}$ & $4.98 \times 10^{5}$ & $5.14 \times 10^{5}$ & $1.35 \times 10^{5}$ & $5.17 \times 10^{5}$ \\
\hline
\end{tabular}

TABLE 4: Analysis of certified reference material (NRCC-DORM-2-Dogfish muscle) $(N=5)$.

\begin{tabular}{lccc}
\hline Element & Certified value $(\mu \mathrm{g} / \mathrm{g})$ & Amount found $(\mu \mathrm{g} / \mathrm{g})$ & Recovery $(\%)$ \\
\hline $\mathrm{Cu}(\mathrm{II})$ & $2.34 \pm 0.16$ & $2.31 \pm 0.13$ & 99 \\
$\mathrm{Ni}(\mathrm{II})$ & $19.4 \pm 3.1$ & $19.10 \pm 1.31$ & 98 \\
$\mathrm{Fe}(\mathrm{III})$ & $142 \pm 10$ & $137.50 \pm 5.82$ & 97 \\
$\mathrm{Zn}(\mathrm{II})$ & $25.6 \pm 2.3$ & $24.90 \pm 1.43$ & 97 \\
$\mathrm{Cr}(\mathrm{III})$ & $34.7 \pm 5.5$ & $34.20 \pm 1.61$ & 99 \\
$\mathrm{Cd}(\mathrm{II})$ & $0.043 \pm 0.008$ & $0.042 \pm 0.002$ & 98 \\
$\mathrm{~Pb}(\mathrm{II})$ & $0.065 \pm 0.007$ & $0.063 \pm 0.003$ & 97 \\
\hline
\end{tabular}

${ }^{\mathrm{a}}$ Mean $\pm \mathrm{SD}$ (standard deviation).

and $\mathrm{Pb}(\mathrm{II})$ were found to be $0.10,0.30,2.50,1.20,1.03,0.08$, and $0.16 \mu \mathrm{g} / \mathrm{L}$, respectively.

3.10. Application of the Presented Procedure. The developed procedure was applied to the determination of investigated metal ions in the microwave digested fish samples as described above. The results obtained are presented in Table 5. European Community has established the maximum allowable levels in fishes of 0.10 and $0.30 \mathrm{mg} / \mathrm{kg}$ of $\mathrm{Cd}$ and $\mathrm{Pb}$, respectively [3]. According to Table 5, Cd and Pb levels in the majority of analyzed fish samples were found higher than their maximum levels. It can be inferred that these fishes can cause toxicological effects on human health.

3.11. Comparison with Other Methods. Determination of metal ions in particularly fishes by the SPE procedure and FAAS detection was compared with other methods and the results are shown in Table 6 . It can be seen that the detection limits for the studied metal ions are satisfactory to those of some separation/preconcentration methods for fish analyses. Preconcentration factor of the method also is superior and comparable to those presented by methods showed in the table.

\section{Conclusion}

The proposed separation/preconcentration method has some advantages such as simplicity and time saving as well as accuracy, sensitivity, and precision. This method is also lowcost because the reusability of Amberlite XAD-7 is as high as 60 cycles without any significant lost of its adsorption properties. The analytical performance of the developed method is comparable with other SPE methods in the literature. The presented method also shows high tolerance to interferences from the matrix ions. The system is also successfully applied to fish samples for the determination of trace amount of $\mathrm{Cu}(\mathrm{II}), \mathrm{Ni}(\mathrm{II}), \mathrm{Fe}(\mathrm{III}), \mathrm{Zn}(\mathrm{II}), \mathrm{Cr}(\mathrm{III}), \mathrm{Cd}(\mathrm{II})$, and $\mathrm{Pb}(\mathrm{II})$ ions. 
TABLE 5: Concentration $(\mathrm{mg} / \mathrm{kg})$ of metals in different parts of the fish species $(N=5)$.

\begin{tabular}{|c|c|c|c|c|c|c|c|}
\hline Fish & $\mathrm{Cu}(\mathrm{II})$ & $\mathrm{Ni}(\mathrm{II})$ & $\mathrm{Fe}(\mathrm{III})$ & $\mathrm{Zn}(\mathrm{II})$ & $\mathrm{Cr}(\mathrm{III})$ & $\mathrm{Cd}(\mathrm{II})$ & $\mathrm{Pb}(\mathrm{II})$ \\
\hline \multicolumn{8}{|c|}{ Dicentrarchus labrax } \\
\hline Scale & $5.8 \pm 0.22^{\mathrm{a}}$ & $4.0 \pm 0.04$ & $284.0 \pm 6.0$ & $3.1 \pm 0.10$ & $15.8 \pm 0.05$ & $0.8 \pm 0.02$ & $0.8 \pm 0.03$ \\
\hline Skin & $1.3 \pm 0.07$ & $0.5 \pm 0.01$ & $42.0 \pm 1.7$ & $1.6 \pm 0.07$ & $3.2 \pm 0.08$ & $0.2 \pm 0.01$ & $0.1 \pm 0.01$ \\
\hline Muscle & $0.7 \pm 0.01$ & $<\mathrm{LOD}$ & $6.1 \pm 0.42$ & $1.2 \pm 0.02$ & $2.5 \pm 0.03$ & $8.7 \pm 0.14$ & $<\mathrm{LOD}$ \\
\hline Gill & $2.7 \pm 0.04$ & $<\mathrm{LOD}$ & $33.1 \pm 0.51$ & $2.6 \pm 0.04$ & $4.8 \pm 0.07$ & $1.1 \pm 0.08$ & $0.1 \pm 0.01$ \\
\hline Liver & $12.3 \pm 0.17$ & $0.2 \pm 0.01$ & $47.2 \pm 0.42$ & $2.1 \pm 0.03$ & $1.4 \pm 0.02$ & $12.3 \pm 0.07$ & $<\mathrm{LOD}$ \\
\hline \multicolumn{8}{|c|}{ Sparus aurata } \\
\hline Scale & $0.9 \pm 0.03$ & $0.7 \pm 0.02$ & $21.2 \pm 0.60$ & $<\mathrm{LOD}$ & $1.6 \pm 0.05$ & $12.2 \pm 0.31$ & $0.2 \pm 0.01$ \\
\hline Skin & $5.1 \pm 0.18$ & $2.4 \pm 0.04$ & $378.3 \pm 2.00$ & $1.1 \pm 0.01$ & $<\mathrm{LOD}$ & $3.2 \pm 0.04$ & $<\mathrm{LOD}$ \\
\hline Muscle & $2.1 \pm 0.08$ & $0.6 \pm 0.01$ & $0.7 \pm 0.03$ & $<$ LOD & $<\mathrm{LOD}$ & $7.2 \pm 0.02$ & $0.2 \pm 0.03$ \\
\hline Gill & $1.4 \pm 0.04$ & $1.5 \pm 0.03$ & $120.1 \pm 2.00$ & $<\mathrm{LOD}$ & $<\mathrm{LOD}$ & $6.1 \pm 0.02$ & $<\mathrm{LOD}$ \\
\hline \multicolumn{8}{|c|}{ Mullus barbatus } \\
\hline Scale & $5.2 \pm 0.04$ & $2.2 \pm 0.05$ & $400.5 \pm 3.01$ & $<\mathrm{LOD}$ & $7.4 \pm 0.07$ & $6.3 \pm 0.12$ & $0.6 \pm 0.04$ \\
\hline Skin & $3.8 \pm 0.07$ & $<\mathrm{LOD}$ & $52.5 \pm 0.72$ & $<\mathrm{LOD}$ & $4.7 \pm 0.04$ & $14.2 \pm 0.07$ & $0.2 \pm 0.02$ \\
\hline Muscle & $5.4 \pm 0.15$ & $0.4 \pm 0.02$ & $12.3 \pm 0.08$ & $<\mathrm{LOD}$ & $<\mathrm{LOD}$ & $13.7 \pm 0.04$ & $<\mathrm{LOD}$ \\
\hline Gill & $6.1 \pm 0.21$ & $0.7 \pm 0.04$ & $308.4 \pm 11.0$ & $0.7 \pm 0.02$ & $<\mathrm{LOD}$ & $10.0 \pm 0.06$ & $0.4 \pm 0.01$ \\
\hline \multicolumn{8}{|c|}{ Merlangius merlangus euxinus } \\
\hline Skin & $0.2 \pm 0.04$ & $0.2 \pm 0.01$ & $18.5 \pm 0.60$ & $<\mathrm{LOD}$ & $0.2 \pm 0.03$ & $6.1 \pm 0.13$ & $0.8 \pm 0.02$ \\
\hline Muscle & $0.1 \pm 0.01$ & $<\mathrm{LOD}$ & $0.2 \pm 0.02$ & $<$ LOD & $<\mathrm{LOD}$ & $11.6 \pm 0.09$ & $0.1 \pm 0.01$ \\
\hline Gill & $<\mathrm{LOD}$ & $<\mathrm{LOD}$ & $130.2 \pm 4.31$ & $<\mathrm{LOD}$ & $<\mathrm{LOD}$ & $14.2 \pm 0.17$ & $0.1 \pm 0.01$ \\
\hline
\end{tabular}

${ }^{\mathrm{a}}$ Mean $\pm \mathrm{SD}$ (standard deviation) of determination in three separate $1 \mathrm{~g}$ tissue type samples.

TABLE 6: Comparison of the proposed method with other SPE methods for determination of metal ions in fish samples by FAAS.

\begin{tabular}{|c|c|c|c|c|}
\hline SPE system & Metal ions & $\mathrm{PF}^{\mathrm{a}}$ & $\mathrm{LOD}^{\mathrm{b}}(\mu \mathrm{g} / \mathrm{L})$ & Reference \\
\hline Amberlite XAD-16/ABSA ${ }^{c}$ & $\mathrm{Cu}, \mathrm{Ni}, \mathrm{Zn}, \mathrm{Co}, \mathrm{Cr}, \mathrm{Fe}, \mathrm{Pb}$ & $60-100$ & $0.69-1.91$ & [19] \\
\hline Amberlite XAD-4/HBA ${ }^{\mathrm{d}}$ & $\mathrm{Co}, \mathrm{Ni}, \mathrm{Cu}, \mathrm{Zn}, \mathrm{Pb}$ & $260-460$ & $0.45-1.37$ & {$[20]$} \\
\hline Activated carbon/BSPD ${ }^{\mathrm{e}}$ & $\mathrm{Cr}, \mathrm{Fe}, \mathrm{Cu}, \mathrm{Ni}, \mathrm{Co}, \mathrm{Zn}$ & 175 & $0.27-0.33 \mathrm{ng} / \mathrm{mL}$ & [36] \\
\hline Schiff base $(\mathrm{L})^{\mathrm{f}} /$ silica/magnetite & $\mathrm{Pb}, \mathrm{Cd}, \mathrm{Cu}$ & 87.5 & $0.12-0.19$ & [37] \\
\hline Activated carbon/BHAPED ${ }^{g}$ & $\mathrm{Fe}, \mathrm{Cu}, \mathrm{Ni}, \mathrm{Co}, \mathrm{Cr}, \mathrm{Zn}$ & 219 & $0.27-0.33 \mathrm{ng} / \mathrm{mL}$ & [38] \\
\hline Polyurethane foam/o- $\mathrm{AP}^{\mathrm{h}}$ & $\mathrm{Pb}, \mathrm{Cd}$ & 250,319 & 0.072 and 0.016 & [39] \\
\hline MWCNTs/IDA ${ }^{\mathrm{i}}$ & V, Cr, Pb, Cd, Co, Cu, As & 66-101 & $0.10-3.4 \mathrm{ng} / \mathrm{mL}$ & {$[40]$} \\
\hline Dowex Optipore SD-2/MTR ${ }^{j}$ & $\mathrm{Cu}, \mathrm{Ni}$ & 50 & 1.03 and 1.90 & [41] \\
\hline Alumina/Sulfur nanoparticle & $\mathrm{Cd}, \mathrm{Cu}, \mathrm{Zn}$, and $\mathrm{Pb}$ & 83.3 & $0.21-0.63$ & {$[42]$} \\
\hline Pumice stone/Penicillium digitatum & $\mathrm{Cr}, \mathrm{Cd}, \mathrm{Mn}$ & 50 & $1.5-2.0 \mathrm{ng} / \mathrm{mL}$ & {$[43]$} \\
\hline Activated carbon/HBAHBN ${ }^{\mathrm{k}}$ & $\mathrm{Cu}, \mathrm{Zn}, \mathrm{Pb}$ & - & $0.65-1.90$ & {$[44]$} \\
\hline Amberlite XAD-7/congo red & $\mathrm{Cu}, \mathrm{Ni}, \mathrm{Fe}, \mathrm{Zn}, \mathrm{Cr}, \mathrm{Cd}, \mathrm{Pb}$ & 300 & $0.08-2.50$ & This work \\
\hline
\end{tabular}

${ }^{\mathrm{a}}$ Preconcentration factor.

${ }^{\mathrm{b}}$ Limit of detection.

${ }^{\mathrm{c}} \mathrm{p}$-Aminobenzene sulfonic acid.

${ }^{\mathrm{d}}$ p-Hydroxybenzoic acid.

${ }^{\mathrm{e}} \mathrm{Bis}$ salicyl aldehyde, 1,3 propan diamine.

f 3-(4-Methoxybenylideneamino)-2-thioxothiazolidin-4-one.

${ }^{\mathrm{g}}$ Bis(2-hydroxyacetophenone)ethylenediamine.

ho-Aminophenol.

${ }^{\mathrm{i}}$ Multiwalled carbon nanotubes, iminodiacetic acid.

j 5-Methyl-4-(2-thiazolylazo)resorcinol.

$\mathrm{k}_{2}$ [2-Hydroxybenzylideneamino] 2-hydroxybenzonitral. 


\section{Competing Interests}

The authors declare that there is no conflict of interests regarding the publication of this paper.

\section{References}

[1] World Health Organization, Evaluation of Certain Food Additives and Contaminants in Forty-First Report of the Joint FAO/WHO Expert Committee on Food Additives, WHO, Geneva, Switzerland, 1993.

[2] World Health Organization, Environment Health Criteria No: 85. Lead: Environmental Aspects, World Health Organization, Geneva, Switzerland, 1989.

[3] European Union, Commission Regulation (EC), no. 1881/2006 of 19 December 2006 setting maximum levels for certain contaminants in foodstuffs, 2006.

[4] A. L. Korai, K. H. Lashari, G. A. Sahato, and T. G. Kazi, "Histological lesions in gills of feral cyprinids, related to the uptake of waterborne toxicants from Keenjhar Lake," Reviews in Fisheries Science, vol. 18, no. 2, pp. 157-176, 2010.

[5] M. B. Arain, T. G. Kazi, M. K. Jamali, N. Jalbani, H. I. Afridi, and A. Shah, "Total dissolved and bioavailable elements in water and sediment samples and their accumulation in Oreochromis mossambicus of polluted Manchar Lake," Chemosphere, vol. 70, no. 10, pp. 1845-1856, 2008.

[6] W. Qu, Y. Zhai, S. Meng, Y. Fan, Q. Zhao, and M. Croch, "Selective solid phase extraction and preconcentration of trace mercury (I) with poly-allylthiourea packed columns," Microchimica Acta, vol. 163, no. 3, pp. 277-282, 2008.

[7] E. Kendüzler and A. R. Türker, "Optimization of a new resin, Amberlyst 36, as a solid-phase extractor and determination of copper(II) in drinking water and tea samples by flame atomic absorption spectrometry," Journal of Separation Science, vol. 28, no. 17, pp. 2344-2349, 2005.

[8] E. Pehlivan and T. Altun, "Ion-exchange of $\mathrm{Pb}^{2+}, \mathrm{Cu}^{2+}, \mathrm{Zn}^{2+}$, $\mathrm{Cd}^{2+}$, and $\mathrm{Ni}^{2+}$ ions from aqueous solution by Lewatit CNP 80 ," Journal of Hazardous Materials, vol. 140, no. 1-2, pp. 299-307, 2007.

[9] M. Atanassova and I. L. Dukov, "Solvent extraction and separation of lanthanoids with mixtures of chelating extractant and 1-(2-pyridylazo)-2-naphthol," Separation and Purification Technology, vol. 49, no. 1, pp. 101-105, 2006.

[10] H. Xu, W. Zhang, X. Zhang, J. Wang, and J. Wang, "Simultaneous preconcentration of cobalt, nickel and copper in water samples by cloud point extraction method and their determination by flame atomic absorption spectrometry," Procedia Environmental Sciences, vol. 18, pp. 258-263, 2013.

[11] A. Mandil, L. Idrissi, and A. Amine, "Stripping voltammetric determination of mercury(II) and lead(II) using screen-printed electrodes modified with gold films, and metal ion preconcentration with thiol-modified magnetic particles," Microchimica Acta, vol. 170, no. 3, pp. 299-305, 2010.

[12] N. Dalali, L. Farhangi, and M. Hosseini, "Solid phase extraction for selective separation/preconcentration of copper using Nbenzoyl N-phenylhydroxyl amine as sorbent modifier," Indian Journal of Chemical Technology, vol. 18, no. 3, pp. 183-187, 2011.

[13] Z. Holubová, M. Moos, and L. Sommer, "Simultaneous determination of metal traces by ICP-MS in environmental waters using SPE preconcentration on different polymeric sorbents," Chemical Papers, vol. 66, no. 10, pp. 899-906, 2012.
[14] A. A. Gouda, "Solid-phase extraction using multiwalled carbon nanotubes and quinalizarin for preconcentration and determination of trace amounts of some heavy metals in food, water and environmental samples," International Journal of Environmental Analytical Chemistry, vol. 94, no. 12, pp. 1210-1222, 2014.

[15] Ç. Arpa and S. Bektaş, "Preconcentration and determination of lead, cadmium and nickel from water samples using a polyethylene glycol dye immobilized on poly(hydroxyethylmethacrylate) microspheres," Analytical Sciences, vol. 22, no. 7, pp. 1025-1029, 2006.

[16] D. Rekha, K. Suvardhan, J. D. Kumar et al., "Solid phase extraction method for the determination of lead, nickel, copper and manganese by flame atomic absorption spectrometry using sodium bispiperdine-1,1' - carbotetrathioate (Na-BPCTT) in water samples," Journal of Hazardous Materials, vol. 146, no. 1-2, pp. 131-136, 2007.

[17] Y. Guo, B. Din, Y. Liu, X. Chang, S. Meng, and M. Tian, "Preconcentration of trace metals with 2-(methylthio)anilinefunctionalized XAD-2 and their determination by flame atomic absorption spectrometry," Analytica Chimica Acta, vol. 504, no. 2, pp. 319-324, 2004.

[18] I. Narin, M. Soylak, L. Elçi, and M. Dogan, "Determination of trace metal ions by AAS in natural water samples after precon. of pyrocatechol violet complexes on an activated carbon column," Journal of Hazardous Materials, vol. 52, no. 6, pp. 1041-1046, 2000.

[19] A. Islam, A. Ahmad, and M. A. Laskar, "Flame atomic absorption spectrometric determination of trace metal ions in environmental and biological samples after preconcentration on a newly developed Amberlite XAD-16 chelating resin containing p-aminobenzene sulfonic acid," Journal of AOAC International, vol. 98, no. 1, pp. 165-175, 2015.

[20] A. Islam, M. A. Laskar, and A. Ahmad, "Characterization of a novel chelating resin of enhanced hydrophilicity and its analytical utility for preconcentration of trace metal ions," Talanta, vol. 81, no. 4-5, pp. 1772-1780, 2010.

[21] É. J. D. Santos, A. B. D. Santos, A. B. Herrmann et al., "Simultaneous determination of $\mathrm{Pb}$ and $\mathrm{Cd}$ in seafood by ICP OES with on-line pre-concentration by solid phase extraction with amberlite XAD-4 after complex formation with DDTP," Brazilian Archives of Biology and Technology, vol. 56, no. 1, pp. 127-134, 2013.

[22] R. Saxena and P. L. Meena, "Flow injection online solid phase extraction system using Amberlite XAD-16 functionalized with 8-hydroxyquinoline for copper and zinc determination by flame atomic absorption spectrometry," RSC Advances, vol. 4, no. 39, pp. 20216-20225, 2014.

[23] P. K. Tewari and A. K. Singh, "Amberlite XAD-7 impregnated with Xylenol Orange: a chelating collector for preconcentration of $\mathrm{Cd}(\mathrm{II}), \mathrm{Co}(\mathrm{II}), \mathrm{Cu}(\mathrm{II}), \mathrm{Ni}(\mathrm{II}), \mathrm{Zn}(\mathrm{II})$ and $\mathrm{Fe}(\mathrm{III})$ ions prior to their determination by flame AAS," Fresenius' Journal of Analytical Chemistry, vol. 367, no. 6, pp. 562-567, 2000.

[24] M. Ince, G. Kaya, and M. Yaman, "Solid phase extraction and preconcentration of cobalt in mineral waters with PAR-loaded Amberlite XAD-7 and flame atomic absorption spectrometry," Environmental Chemistry Letters, vol. 8, no. 3, pp. 283-288, 2010.

[25] G. Purna Chandra Rao, S. Satya Veni, M. Madhava Rao, K. Pratap, M. C. Wang, and K. Seshaiah, "Amberlite XAD-7 impregnated with morpholine dithiocarbamate as trace metal extractant," Toxicological and Environmental Chemistry, vol. 88, no. 1, pp. 65-76, 2007. 
[26] P. K. Tewari and A. K. Singh, "Preconcentration of lead with Amberlite XAD-2 and Amberlite XAD-7 based chelating resins for its determination by flame atomic absorption spectrometry," Talanta, vol. 56, no. 4, pp. 735-744, 2002.

[27] T. Şişmanoğlu, S. Pura, and A. S. Baştuğ, "Binary and ternary metal complexes of Congo red with amino acids," Dyes and Pigments, vol. 70, no. 2, pp. 136-142, 2006.

[28] M. Abd-Elmottaleb, H. A. Hammad, S. M. Shaaban, and M. ElDosoky, "Electrical conductivity and phase transition studies of some selected Congo red-metal complexes," Journal of Thermal Analysis, vol. 46, no. 5, pp. 1459-1466, 1996.

[29] B. Salih, A. Denizli, and E. Pişkin, "Congo red-attached poly(EGDMA-HEMA) micro beads for removal of heavy metal ions," Separation Science and Technology, vol. 31, no. 5, pp. 715727, 1996.

[30] B. Salih, A. Denizli, B. Engin, A. Tuncel, and E. Pişkin, "Congo red attached poly(EGDMA-HEMA) microspheres as specific sorbents for removal of cadmium ions," Journal of Applied Polymer Science, vol. 60, no. 6, pp. 871-877, 1996.

[31] A. Denizli, G. Köktürk, B. Salih, A. Kozluca, and E. Pişkin, "Congo red- and $\mathrm{Zn}(\mathrm{II})$-derivatized monosize poly(MMAHEMA) microspheres as specific sorbent in metal chelate affinity of albumin," Journal of Applied Polymer Science, vol. 63, no. 1, pp. 27-33, 1997.

[32] I. Durukan, M. Soylak, and M. Doğan, "Enrichment and separation of $\mathrm{Fe}(\mathrm{III}), \mathrm{Mn}(\mathrm{II}), \mathrm{Ni}(\mathrm{II})$, And $\mathrm{Zn}(\mathrm{II})$ as their congo red chelates on multiwalled carbon nanotube (MWCNT) disk in food and water samples," Atomic Spectroscopy, vol. 34, no. 1, pp. 20-25, 2013.

[33] B. Dybem, "Field sampling and preparation of subsamples of aquatic organisms for analysis of metals and organochlorides," Fisher Technology, vol. 212, pp. 1-13, 1983.

[34] M. D. Granado-Castro, M. D. Galindo-Riaño, and M. GarcìaVargas, "Separation and preconcentration of cadmium ions in natural water using a liquid membrane system with 2acetylpyridine benzoylhydrazone as carrier by flame atomic absorption spectrometry," Spectrochimica Acta-Part B Atomic Spectroscopy, vol. 59, no. 4, pp. 577-583, 2004.

[35] Y. Liu, Y. Guo, S. Meng, and X. Chang, "Online separation and preconcentration of trace heavy metals with 2,6dihydroxyphenyl-diazoaminoazobenzene impregnated amberlite XAD-4," Microchimica Acta, vol. 158, no. 3-4, pp. 239-245, 2007.

[36] M. Ghaedi, A. Shokrollahi, A. H. Kianfar, A. S. Mirsadeghi, A. Pourfarokhi, and M. Soylak, "The determination of some heavy metals in food samples by flame atomic absorption spectrometry after their separation-preconcentration on bis salicyl aldehyde, 1,3 propan diimine (BSPDI) loaded on activated carbon," Journal of Hazardous Materials, vol. 154, no. 1-3, pp. 128-134, 2008.

[37] H. Bagheri, A. Afkhami, M. Saber-Tehrani, and H. Khoshsafar, "Preparation and characterization of magnetic nanocomposite of Schiff base/silica/magnetite as a preconcentration phase for the trace determination of heavy metal ions in water, food and biological samples using atomic absorption spectrometry," Talanta, vol. 97, pp. 87-95, 2012.

[38] M. Ghaedi, A. Shokrollahi, A. H. Kianfar et al., "Preconcentration and separation of trace amount of heavy metal ions on bis(2-hydroxy acetophenone)ethylendiimine loaded on activated carbon," Journal of Hazardous Materials, vol. 162, no. 2-3, pp. 1408-1414, 2009.
[39] N. Burham, S. M. Abdel-Azeem, and M. F. El-Shahat, "Removal of $\mathrm{Pb}$ and $\mathrm{Cd}$ from aqueous media and fish liver using novel polyurethane foam functionalized with pyrazolone as a new metal ion collector," Central European Journal of Chemistry, vol. 7, no. 3, pp. 576-585, 2009.

[40] J. Wang, X. Ma, G. Fang, M. Pan, X. Ye, and S. Wang, "Preparation of iminodiacetic acid functionalized multi-walled carbon nanotubes and its application as sorbent for separation and preconcentration of heavy metal ions," Journal of Hazardous Materials, vol. 186, no. 2-3, pp. 1985-1992, 2011.

[41] M. Tuzen, M. Soylak, D. Citak, H. S. Ferreira, M. G. A. Korn, and M. A. A. Bezerra, "A preconcentration system for determination of copper and nickel in water and food samples employing flame atomic absorption spectrometry," Journal of Hazardous Materials, vol. 162, no. 2-3, pp. 1041-1045, 2009.

[42] K. Ghanemi, Y. Nikpour, O. Omidvar, and A. Maryamabadi, "Sulfur-nanoparticle-based method for separation and preconcentration of some heavy metals in marine samples prior to flame atomic absorption spectrometry determination," Talanta, vol. 85, no. 1, pp. 763-769, 2011.

[43] S. Baytak and A. R. Türker, "Determination of chromium, cadmium and manganese in water and fish samples after preconcentration using Penicillium digitatum immobilized on pumice stone," Clean-Soil, Air, Water, vol. 37, no. 4-5, pp. 314318, 2009.

[44] K. Chalapathi, "Analysis of heavy metals in fish samples after preconcentation on activated carbon modified with 2[2-hydroxybenzylideneamino] 2-hydroxybenzonitral," International Journal of Analytical and Bioanalytical Chemistry, vol. 2, no. 1, pp. 122-128, 2012. 

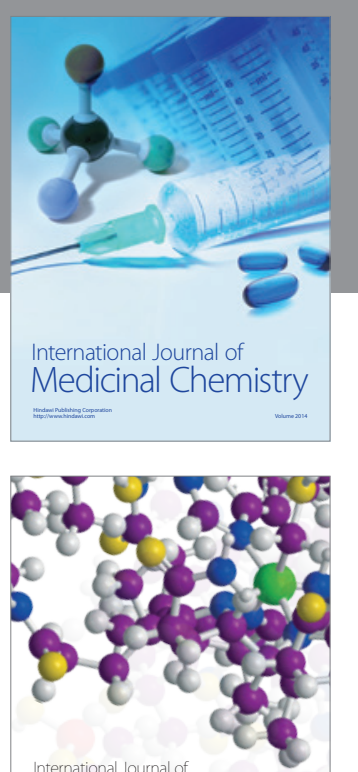

Carbohydrate Chemistry

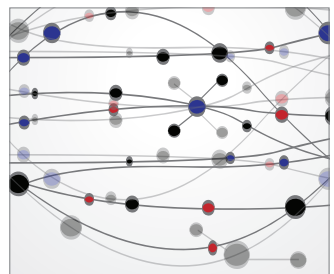

The Scientific World Journal
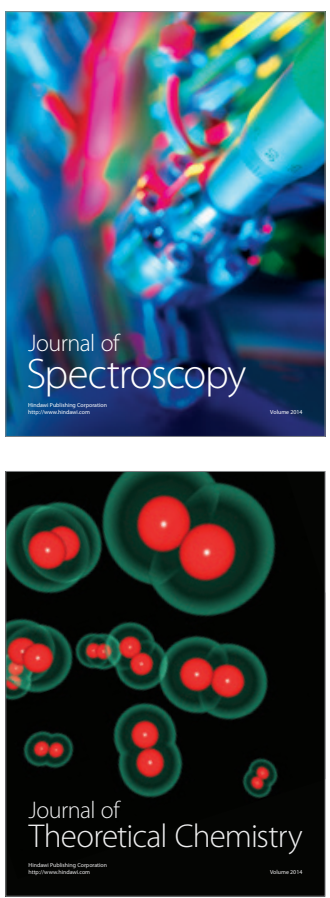
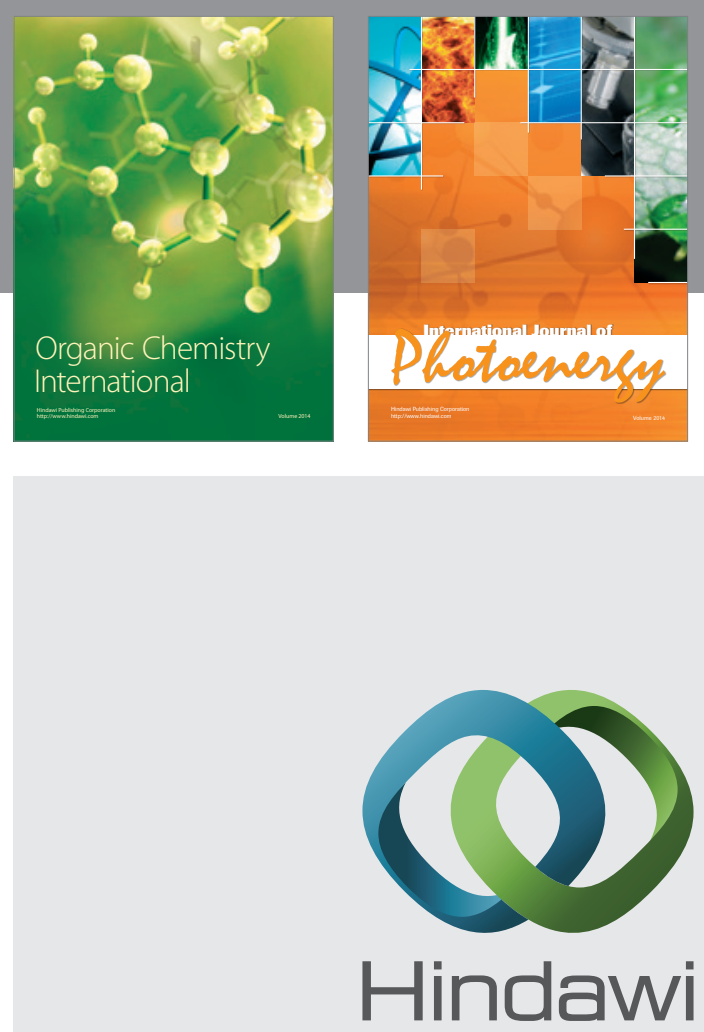

Submit your manuscripts at

http://www.hindawi.com

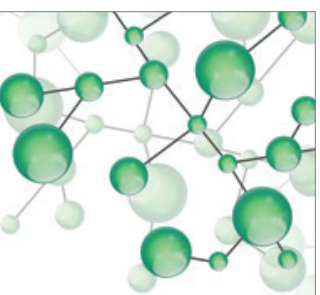

International Journal of

Inorganic Chemistry

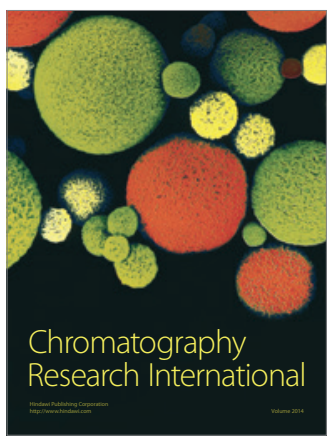

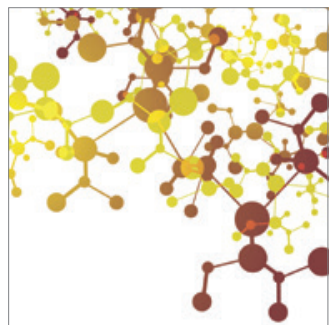

Applied Chemistry
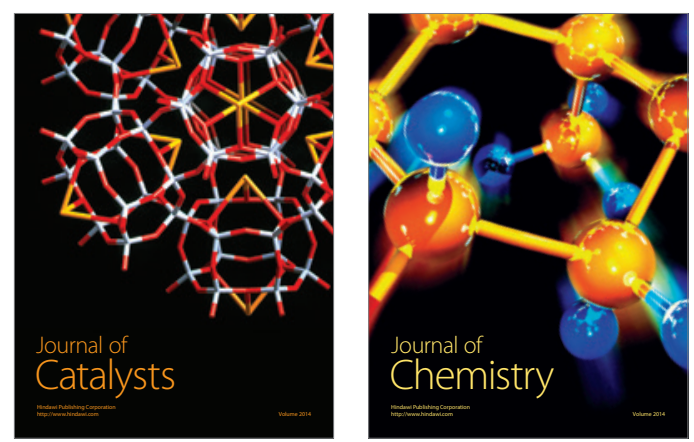
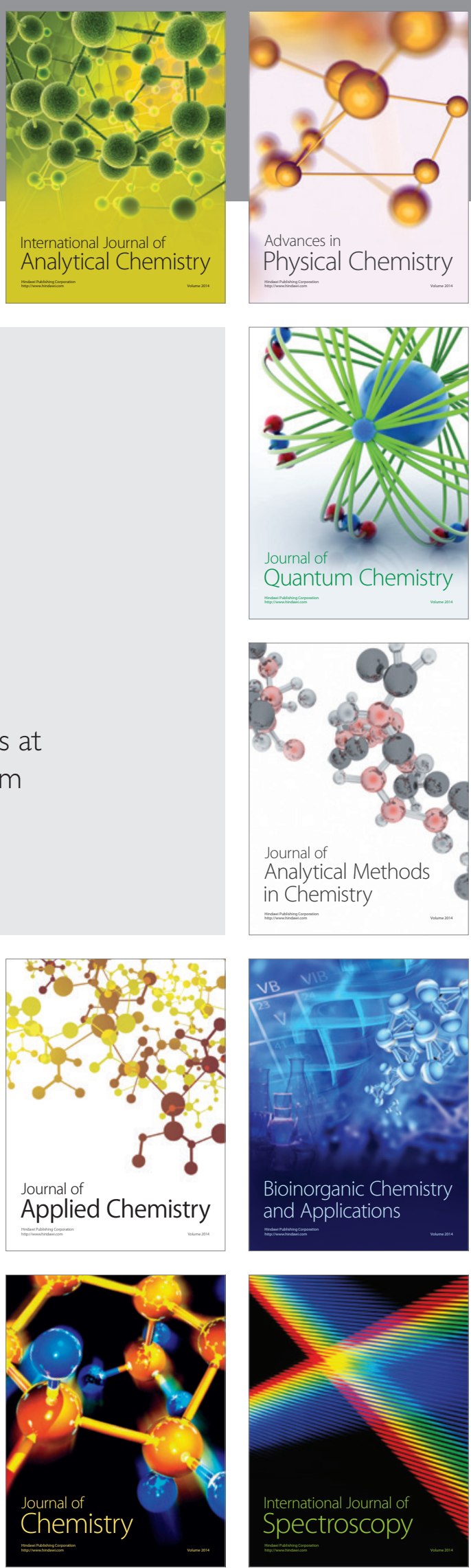